\title{
A Brief Discussion on the Reform and Development of College English Teaching under the Historical Background of "Internet+"
}

Xu Xia

Yunnan Jiaotong College, Kunming, Yunnan, 650500, China

\begin{abstract}
With the rapid development of China's economy, the era of "Internet+" has been ushered in, and the appearance of "Internet+" brings new opportunities and challenges for college English teaching and also has generated certain influence on the educational cause. This paper discusses the reform and innovation of college English teaching in the "Internet +" era and after specific analysis and research on teaching method, teaching concept and learning methods, puts forward the corresponding measures to comprehensively improve college students' English competency and then cultivate comprehensive quality talents for China.
\end{abstract}

Keywords: Internet+; college English teaching; reform; development; implementation strategy

Published Date: January 2018

Published Online: $31^{\text {st }}$ January 2018

Corresponding Author: Xu Xia, Yunnan Jiaotong College, Kunming, Yunnan, 650500, China, 2691616494@qq.com

\section{Introduction}

As social economy progresses, "Internet+" has risen to be the focus at present and has exerted certain influence on college English teaching. Efforts should be made to organically integrate college English with the Internet, stimulate students' enthusiasm for learning and then improve teaching quality and effect and promote diversified development of college English teaching.

\section{A brief discussion on the reform and development of college English teaching under the historical background of "Internet+"}

The arrival of "Internet + " era has comprehensively changed the way people get knowledge and also changed the traditional English teaching concept ${ }^{[1]}$. The rapid development of the Internet has completely changed the traditional model in the past and students' learning is no longer restricted by conditions and reflects the teaching achievements in the meantime.

\subsection{Understanding on traditional teaching concepts}

The "Internet + " era drives the development of micro-course teaching and then assists English teaching. In such a way, students can freely learn varieties of contents without being restricted by objective conditions, thus reflecting the dominant role of students and making students guide the class. In such a learning atmosphere, teachers make use of the Internet platform, positively conduct English teaching, completely subvert the traditional teaching mode, strengthen college students' English ability and promote the sound development of English education.

\subsection{Understanding on traditional teaching method}

With the rapid development of the "Internet+", make open management on students' education and then effectively cultivate students' independent and innovative learning competency without being restricted to text books and then widen students' horizon and exercise students' ability: [2]. Teachers organically integrate the classroom teaching with the "Internet +" technology, and let students study independently, which then effectively strengthens 
students' learning level, changes the opinion of students to that "I want to study" from that "I am learning" and to be active from being passive and then inspire students' passion in learning. Besides, students can study independently according to their own actual situation, independently control time, actively study and completely break the traditional teaching mode and take the initiative in learning. The use of Internet in teaching can effectively improve the teaching effect, comprehensively show teaching contents, let students learn much more knowledge and improve their English ability and then strengthen the teaching quality.

\subsection{Influence on traditional teaching activities}

In the new era, the Internet propels the development of the education cause and imposes higher requirements on teachers' comprehensive quality. As a result, teachers should not only possess professional knowledge and ability and but also use the Internet technology in the classroom and organically integrate both and then highlight teaching achievements. In the process of English teaching, teachers should lay stress on students' actual situation and personal characteristics and carry out teaching of different ways on students in an attempt to improve students' learning level, inspire learning pleasure and strengthen students' English quality. For example, in class, teachers can adopt the learning method of teamwork cooperation to mobilize the classroom atmosphere. And teachers should also study continually to improve their own quality to further upgrade teaching quality and efficiency. In class, teachers should skillfully use the Internet, positively interact with students, organically integrate teaching contents with modern technology, fully tap students' potentials and strengthen students' deep understanding on English.

\section{A Brief discussion on the teaching mode in the reform and development of college English teaching under the historical background of "Internet+"}

The arrival of the "Internet+" era has significantly changed the education mode in China. Micro-course teaching is integrated into English classroom in college, which changes the traditional teaching mode, fully meets students' requirements for English learning and then strengthens students' English ability in the meanwhile ${ }^{[3]}$. Diversified teaching mode fully shows modern teaching concept and lays a stable foundation for students' English education.

\subsection{Teaching concept of "MOOC"}

The teaching concept of "MOOC" is to realize English teaching method which is not restricted by the traditional teaching mode and then improve students' comprehensive ability based on the Internet. The application of MOOC teaching tools in English classroom in college can effectively promote the development of education course, organically integrate text contents with Internet, give full play to students' dominant role and cultivate students' English learning ability.

However, in the teaching process of college English, teachers should not excessively use the foreign teaching mode, but pay attention to students' actual situation, carry out the relevant teaching and use the teaching method of MOOC through deep understanding on knowledge and then establish an innovative and characteristic teaching mode. Besides, teachers should use $\mathrm{MOOC}$ to carry out teaching activities, positively interact with students, alleviate students' learning stress, know better of students and then adopt correct measures according to students' specific situations. Correct guidance to students to study independently is also expected to effectively improve students' English ability and perfect teaching concept.

\subsection{Teaching concept of "micro-course"}

The advent of the "Internet + " era makes MicroCourse an important method in college English teaching. The so-called Micro-Course teaching refers to recording key points and difficulties in teaching materials as a small video or film, and then show them to students. Micro-Course is consisted of micro-video and micro-resource aiming to explain specific knowledge points and help students to learn difficulties and key points to make students understand deeply. 
Compared with MOOC, it is obvious that MicroCourse is more practical for its highlight on main ideas, explicit provision of contents and convenience for applying. However, when applying Micro-Course, the video can't be recorded too long but within ten minutes. Experiments have proven that videos within ten minutes is more reasonable to adapt to modern students' habits. As for Micro-Course teaching, teachers should make the plan carefully in order to make students to learn knowledge deeply after Micro-Course study.

3 A brief discussion on measures of reform and development of college English teaching under the historical background of "Internet+"

\subsection{Create WeChat English learning platform}

With the advancement of technology, more and more people begin to communicate by WeChat ${ }^{[4]}$. Therefore, teachers may also use WeChat to teach through creating a WeChat group to send out study files to students for learning. Also teachers may create a QR code on study contents for easy download which is easy and convenient. Moreover, through group chat, teachers may have good communication with students to make the relationship between teachers and students closer and master the conditions of students' learning conditions better. Students may directly ask the teacher on unclear questions. All the above may improve teaching performance. In the current stage, it is very common to apply the WeChat platform in English learning which may not only improve students' oral English ability but also strength students' understanding on English learning deeply. The WeChat platform may motivate students' enthusiasm which may help students learn better, enrich teaching resources, and also deepen understanding and consolidate knowledge.

\subsection{Create Internet teaching mode}

In the process of college English teaching, creating the Internet teaching mode may positively promote English learning, develop teaching vision and integrate different parts in teaching, managing and appraising. In the management module, leaders of college carry out dynamic management over students to distribute teaching contents in a unified manner, manage specific items and meet students' requirements based on actual conditions.

In the teaching processing, language expression is crucial. In order to improve students' language skills, basic courses, development courses and extended courses are required ${ }^{[5-7]}$. The key to basic courses is to strengthen the listening, speaking, reading and writing competence of students. And the key to extended courses is to expand students' vision to improve their daily communication ability. And the key to development courses is to link the development of English teaching to strengthen the comprehending ability of students for better application. Moreover, in the process of Internet teaching, it may provoke the awareness of students on independent learning to form the good studying habit to improve the comprehending abilities. ${ }^{[8-10]}$

\section{Conclusion}

All in all, the arrival of Internet+ era brings both opportunities and challenges to college English teaching. Meanwhile, the reform and development of college English teaching provides advancement conditions. In the process of daily teaching, teachers shall follow the steps of the times closely to apply effective resources to improve students' comprehending abilities and promote the development of college English teaching while cultivating more excellent talents for China and society to step further on China's education industry.

\section{References}

[1] HaiAn. Make Full Use of Internet Teaching Resources To Promote the Reform of College English Teaching[J]. Journal of Shandong Youth Administrative Cadres College, 2012(5):138-139. (in Chinese)

[2] ChunxiZhao. A Tentative Idea on the Reform of College English Teaching Based on MOOC Model[J]. Science and Technology Innovation Herald, 2015(17):144-145. (in Chinese)

[3] JiaGuo. A Preliminary Study of College English 
Teaching Reform Based on Mobile Internet Personalized Learning[J]. Campus English (First Ten Days), 2015(10):27-27 (in Chinese)

[4] YanchunYang. Application of "Internet+" Era of Mobile Learning in College English Teaching[J]. Journal of Higher Education, 2016(6):117-118. (in Chinese)

[5] GuifangZhou. Study on University English Teaching Model in the Internet+ Era[J]. English Square, 2016(2):86-88. (in Chinese)

[6] Lili Wang, Fan Yang. The Study of English Teaching Reform and Development of the University under the Background of "Internet +"[J]. Heilongjiang Researches on Higher Education, 2015(8):159-162. (in Chinese)

[7] Yuan Huang. The Reform and Development of the
University English Teaching under the Background of "Internet + "[J]. English Square: Academic Research, 2016(8):68-69. (in Chinese)

[8] Ying Zhang. The Reform and Development of the University English Teaching under the Background of "Internet +"[J]. Campus English, 2017(21):23-23. (in Chinese)

[9]Ling Zhan. Discussion on the Reform of College English Teaching under the Background of "Internet +"[J]. Journal of New Education Era Electronic: Student Edition, 2016(5). (in Chinese)

[10] Hongxia Wang. The Reform Practice and Effectiveness of the University English Teaching under the Background of "Internet + "[J]. English Square: Academic Research, 2016(8):115-116. (in Chinese) 